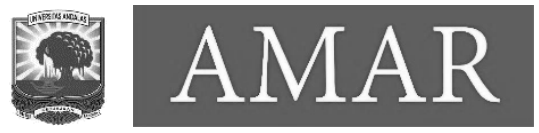

AMAR (Andalas Management Review)

Vol. 4, No. 1 (2020) 100-119

The Management Institute, Faculty of Economics, Universitas Andalas

ISSN (Print) 2476-9282 | ISSN (Online) 2548-155X

\title{
The Effect of Firm Sizes, Profitability, Dividend Policy, Asset Structure, Sales Growth and Free Cash Flow on Debt Policy (On Manufacturing Companies Listed on The Indonesia Stock Exchange 2015-2018)
}

\author{
Ria Nurdania, Ika Yustina Rahmawatib \\ a,b Univeritas Muhammadiyah Purwokerto,nurdaniria2@gmail.com
}

\begin{abstract}
The study aims to examine the effect of company size, profitability, dividend policy, asset structure, company growth and free cash flow on debt policy. The object of this study uses manufacturing companies listed on the Indonesia Stock Exchange. The data used is secondary data in the form of annual financial statements for the 2015-2018 period. The collection technique used in this study was purposive sampling while the data analysis techniques used in this study were descriptive statistics, classic assumption tests, multiple regression analysis and hypothesis testing. The analysis show that the size of the company has a negative and not significant effect on debt policy, profitability has a negative and significant effect on debt policy. Dividend policy variables and asset structure has a negative and significant effect on debt policy. While sales growth and free cash flow has no effect on debt policy.

Keyword: company size, profitability, dividend policy, asset structure, sales growth, free cash flow, debt policy
\end{abstract}

\section{INTRODUCTION}

A manufacturing company is a company whose activities manage raw materials or raw materials so that it becomes finished goods to be sold to consumers. There is a phenomenon of debt policy that occurs in the goods and consumption sector at PT SarigunaPrimatirtaTbk (CLEO). Sales of bottled drinking water SarigunaPrimatirta increased for all segments, be it sales in bottles, gallons, glass, and other sales. At the end of September 2019, total assets of CLEO reached Rp 1.22 trillion, an increase of 46.04\% from the end of 2018, which was Rp 833.93 billion. CLEO's total liabilities soared $146.07 \%$ to Rp 488.34 billion. Total liabilities increased because there was an increase in operating debt $29.66 \%$, an increase in bank loans by $608.33 \%$, and an increase in debt financing of financial institutions and other debts by $79.24 \%$. The increase in liabilities is to support investment activities and increase the company's working capital. Pocketed an investment loan from Bank Mandiri in March 2019. As of September, the outstanding investment credit balance was Rp 219.76 billion. While CLEO assets increased due 
to the purchase of assets in the form of land and buildings, machinery and vehicles (www.kontan.id).

In a company a manager is given an important role by shareholders in terms of managing and running the company so that company goals can be achieved together. One of the activities in managing and running a company is by making decisions about important activities in terms of fund raising and how to utilize the funds. The decision made must be in accordance with the main objectives of a company. Decisions taken by managers tend to protect and fulfill their interests first rather than meeting the interests of the owner such as expanding to improve salary status. One alternative manager to obtain funds for expansion is to increase debt.

Debt policy is a policy taken by management in order to obtain a source of financing for the company so that it can be used to finance the company's operational activities (Putra, 2017). One that influences the debt policy is the size of the company. Company size is the size of the company's resources. These resources include assets, technology, intellectual property, and so on. With the presence of large resources, companies can invest in current assets and fixed assets (Novitasari, 2015). The results of research by Suryani (2015 \& 2016), Husna (2016) which states that the size of the company has no effect on debt policy. Unlike the research by Iwan (2016), Mardiyati (2018), Novitasari (2015), Ifada (2017) which states that the size of the company significant positive effect on debt taxation. From the discussion above there is a formulation of the problem whether the size of company has a positive and significant impact on debt policy?.

Besides Return on assets (ROA) or profitability also affect debt policy. This ratio measures the overall effectiveness of management aimed at the size of the level of profits obtained in relation to sales and investment. The results of research from Ahyuni(2018), Novitasari (2015), Sheisarvian (2015), Nafisa (2016) which states Return on assets negatively affect debt policy. Likewise research by Mardiyati (2018), Putra (2017) which states that there is a positive effect on return on assets for debt policy means that returns on corporate assets affect debt policy, because companies need large funds and cannot be separated from debt, especially in corporate funding sources. From the discussion above there is a problem statement whether profitability has a negative and significant impact on debt policy?. 
Another factor influencing debt policy is dividend policy. Where for the first time the company will take advantage of funding from retained earnings, if retained earnings are insufficient then debt funding will be used. The results of research by Suryani (2016), Ifada (2017) which states that the dividend policy has a positive effect on debt policy. While the study of Sheisarvian (2015) which states that the dividend policy has a negative and significant effect on debt policy. From the discussion above there is a formulation of the problem whether the dividen policy has a positive and significant impact on debt policy?.

Asset structure is a determination of how much allocation for each component of assets, both in fixed assets and current assets (Hanafi 2016). The results of research from Mardiyati (2018) stated that the structure of assets does not affect the debt policy. Different from the results of research from Lestari (2016) which states that the structure of assets has a significant effect on debt policy. There is also research from Herdiana (2016) which states that the structure of assets influences negative and significant effect on debt policy. From the discussion above there is a formulation of the problem whether the asset structure has a positive and significant effect on debt policy?.

In addition to the above factors, sales growth also influences debt policy. Brigham and Houston (2013) argue that companies with stable sales can be safer in obtaining lots of loans and bear higher fixed costs compared to companies with unstable sales. The results of research by Andriati (2016), which states sales growth has an effect on debt policy. Supported research by Novitasari (2015), Irawan (2016) which states that sales growth has a significant positive effect on debt policy. From the discussion above there is a formulation of the problem whether sales growth has a positive and significant effect on debt policy?.

Free Cash Flow according to Putra (2017) defines free cash flow is cash flow which is the remainder of the funding of all projects that results in a positive net present value discounted at the level of relevant capital costs. Free cash flow reflects profit or return for providers of capital including debt or equity. The results of research fromuryani (2015 \& 2016) state that free cash flow does not affect debt policy. Andriati (2016) which states that free cash flow influences debt policy. Strengthened research by Indraswari (2016) and Natasia (2015) which states that free cash flow has a significant positive effect on debt policy. From the discussion above there is a formulation of the problem whether free cash flow has a positive and significant effect on debt policy?. 


\subsection{Literature Review}

\section{a. Capital Structure Theory}

Modigliani-Miller Theory is a modern capital structure theory that began in 1958. Modigliani-Miller managed to prove that the value of a company is not influenced by its capital structure (Sheisarvian, 2015). In 1963, MM published an article following the MM theory in 1958. Assumptions What was changed was the existence of tax on company income. With this tax, MM concludes that the use of debt will increase the value of the company because the cost of debt interest is a cost that reduces tax payments. Fahmi (2014: 182-183) states that in general there are two theories that discuss capital structure, namely:

1) Balancing Theories

Balancing Theories is a theory that explains the debt policy adopted by companies to seek and add credit by either lending or by issuing bonds.

\section{2) Pecking Order Theories}

Pecking Order Theories is a theory that explains a policy adopted by a company to seek additional funds by selling its assets.

\section{b. Agency Theory}

Agency theory according to Jensen and Meckling (1976), that is, agency relationship arises when a person or more (principal) employs another person to do a job in accordance with the interests of the principal by delegating some authority for decision making funding. In this agency theory the principal is the shareholder, and the agent is the management that manages the company (Sheisarvian, 2015).

c. Debt Policy

According to Fahmi (2014: 153) debt is a liability. Liabilities or debts are liabilities owned by companies that originate from external parties both from banking loan sources, leasing, bond sales and the like, therefore an obligation is obligatory for companies carrying out these obligations, and if these obligations are not carried out in a timely manner it will be possible for a company to receive sanctions and consequences.

d. Company Size

According to Mardiyati (2018) the size of the company is one of the things that companies consider in determining their debt policy because the large size of the 
company certainly has a larger supporting resource compared to the smaller size of the company.

e. Profitability

Profitability is the ability of a company to generate profits for a certain period. One of the company's ability to repay debt can be seen from creditors in their ability to generate profits (Husna, 2016). The higher the profitability of a company, the lower the debt policy of a company because with a high level of profitability the company generally uses debt in relatively small amounts with a high rate of return on investment the company can make capital with retained earnings (Husna, 2016).

f. Dividend Policy

Dividends are part of the profits derived by the company and will be distributed to company owners or investors. Dividend policy is a policy made by a company in determining how much of a profit must be paid to shareholders and how much should be held back in the company (Sheisarvian, 2015).

g. Structure of Assets

Assets are defined as economic benefits that will be received in the future, or will be controlled by the company as a result of certain transactions or events. Assets are an economic source of the organization that will be used to carry out its activities. The main attribute or asset is the ability to provide services or benefits to organizations that use these assets (Hanafi, 2016: 29).

h. Sales Growth

Sales growth is an increase in the number of sales from year to year. The company's sales can increase because the investment made by the company also increases. In funding large investments, companies tend to use large debts (Novitasari 2015).

i. Free Cash Flow

According to Brigham and Houston (2010: 109) free cash flow is the company's cash flow that is really available to be paid to investors (shareholders and creditors) after the company invests in fixed assets, new products and working capital needed to meet the needs ongoing company operations.

\subsection{Hypothesis Framework}
a. Effect of Company Size on Debt Policy 
The size of the company is the amount of resources owned by the company. These resources include assets, technology, intellectual property, and so on. The size of a large company certainly requires more funds than a small company. This decision is related to the pecking order theory which states that if the retained earnings are insufficient, then debt becomes the next decision. can be fulfilled with its own funds (Suryani, 2015). Based on the explanation above, company size has a positive and significant effect in line with research from Nafisa (2016) and Irawan (2016), Mardiyati (2018), Novitasari (2015), Ifada (2017). H1: Company size has a positive and significant effect on DER.

\section{b. Effect of Profitability on Debt Policy}

Based on the pecking order theory, if a company needs funds, the first priority is to use internal funds, namely from retained earnings, but if you have to seek external funding (external), debt will be the top priority. This theory prioritizes internal funding will reduce external funding, namely debt. Companies that have a high level of profitability will be able to generate more funds for the company so that it can be used as a cover liability and have an impact on the reduced level of debt use by the company (Sheisarvian, 2015: 8). Based on the explanation above, profitability has a negative and significant effect on the debt policy of Novitasari (2015) and Irawan (2016), Ahyuni(2018) and Sheisarvian (2015). H2: Profitability has a negative and significant effect on DER.

c. Effect of Dividend Policy on Debt Policy

Dividend policy will have an influence on the level of use of a company's debt. This can be strengthened by the Pecking Order Theory which explains the sequence of companies in making funding decisions. For the first time the company will utilize funding from retained earnings, if retained earnings are insufficient then debt financing will be used. Thus, if a company increases its dividend payments, the funds available for corporate funding in the form of retained earnings will be smaller (Suryani, 2015). So as to meet the needs of company funds, managers are more likely to use more debt.

In financial management, the company's main goal is to increase the prosperity of its owners or shareholders. The level of prosperity of the owners or shareholders is seen by how much the company uses a high level of dividends. Bounding the explanation above dividend policy has a positive and significant effect on debt policy. This is supported by 
research conducted by Suryani (2015 \& 2016), Ifada (2017) and Indraswary (2016). H3: Dividend Policy has a positive and significant effect on DER.

\section{d. Effect of Asset Structure on Debt Policy}

Asset structure is related to company assets that can be used as collateral that is more flexible and will tend to use larger debt than companies that have inflexible asset structures. Existing asset structure in a company will affect the debt policy carried out by the company. The amount of wealth can be used as collateral for the company, meaning that creditors will more easily provide loans if accompanied by large collateral, the creditor in considering the loan will pay attention to the structure of assets (I Putu, 2017).

Based on the statement above in accordance with the pecking order theory which is a funding structure model that follows a hierarchy derived from retained earnings, debt and finally equity to fill the composition of the company's capital structure. Company wealth is sourced from the funding structure which includes retained earnings, debt, and equity. Based on the description above the asset structure has a positive and significant effect on debt policy. This is in accordance with research conducted by I Putu (2017), Indana (2015) and Wahidahwati (2015). H4: Asset Structure has a positive and significant effect on DER.

e. Effect of Sales Growth on Debt Policy

The growth rate of sales is the result of a comparison between the difference in sales in the current year and the sales of the previous year with sales in the previous year. Companies that have stable sales can be safer in getting a lot of loans and bear higher fixed costs compared to companies whose sales are unstable. can increase because the investment made by the company also increases (Mardiyati, 2018). This is in accordance with the pecking order theory which explains why profitable companies generally borrow in small amounts. That's because the company's internal funding sources are sufficient to meet the investment needs derived from profits obtained by the company (Mardiyati, 2018). Based on the explanation above, sales growth has a positive effect on the debt policy of Geovana (2015) and Irawan (2016), Mardiyati (2018) and Novitasari (2015). H5: Sales growth has a positive and significant effect on DER. 


\section{f. Effect of Free Cash Flow on Debt Policy}

Free Cash Flow is the amount of a company's discretionary cash flow to buy additional investments, pay off debt, buy treasury shares, or just to increase company liquidity. With the debt can be used to control the excessive use of free cash flow by managers. In addition shareholders will also enjoy more control over their management team. This is in accordance with agency theory which explains the relationship between shareholders and agents as management who manages the company, for example if a company issues new debt and uses the proceeds to repurchase outstanding ordinary shares, then management must pay cash to cover this debt, simultaneously reducing the amount of cash flow that is in management to be mocked (Indraswary 2016). Based on the explanation above, free cash flow has a positive and significant effect on Andriati (2016),

Natasia (2015) and Indraswary (2016) debt policies. H6: Free cash flow has a positive and significant effect on DER.

\section{METHOD}

This type of research is quantitative research. The population in this study is manufacturing companies listed on the Indonesia Stock Exchange whose financial statements are published during the 2015-2018 period. The sample in this study were 15 manufacturing companies listed on the Indonesia Stock Exchange 2015-2018. The withdrawal of the sample from this study used purposive sampling, namely the technique of determining the sample with certain considerations (Sugiono, 2015: 67). Data sources used in this study were secondary data, which is based on financial statements published by the Indonesia Stock Exchange for the period 2015-2018. The analytical method used in this study is multiple linear regression analysis by testing the classical assumptions first, namely data normality test, multicollinearity test, heterocedasticity test, and test autocorrelation.

\subsection{Operational Definition}

a. Debt policy

Debt policy is a company funding policy that is sourced externally. The debt policy variable can be symbolized by the debt to equity ratio which can be formulated as follows (Fahmi, 2014: 178): 


$$
\mathrm{DER}=\frac{\text { totaldebt }}{\text { totalequity }}
$$

b. Company size

Is the ratio of the natural logarithm of sales. This variable is formulated as follows (Mardiyati, 2018):

$$
\text { Company Size }=\text { Ln (Total Assets) }
$$

\section{c. Profitability}

Profitability ratios calculate the company's ability to get profits (Hanafi, 2016: 42). In this research, the Return on Assets (ROA) proxy is used to measure the company's profitability. ROA formula as follows:

$$
\mathrm{ROA}=\frac{\text { netprofit }}{\text { totalassets }}
$$

\section{d. Dividend policy}

This ratio (dividend payout ratio) looks at the portion of earnings (income) paid as dividends to investors. Other parts that are not distributed will be reinvested into the company (Hanafi, 2016: 83). Which is formulated as follows:

$$
\mathrm{DPR}=\frac{\text { Dividenpershare }}{\text { earningpershare }} \times 100 \%
$$

\section{e. Asset structure}

Asset structure related to company assets that can be used as flexible collateral will tend to use more debt than companies that have inflexible asset structures. The measurement scale used is a ratio scale and is formulated as follows (Mardiyati, 2018):

$$
\mathrm{SA}=\frac{\text { fixedassets }}{\text { totalasset }}
$$

f. Sales growth

Sales growth is the result of a comparison between the difference in sales in the current year and sales in the previous year with sales in the previous year (Mardiyati, 2018). Company growth can be calculated using the following formula: 


$$
\text { Sales growth }=\frac{\text { sales years } t-\text { salesyearst }-1}{\text { salesyearst }-1}
$$

g. Free cash flow

Free cash flow is assumed from the company's excess cash flow that can be distributed to creditors or shareholders that are no longer needed for working capital or investment in fixed assets. According to Brigham and Houston (2010: 109) free cash flow can be calculated using the following formula:

$$
\mathrm{FCF}=\mathrm{CFO}-\mathrm{CFI}
$$

Explanation :

FCF: free cash flow

CFO: cash flow operation

CFI: cash flow investment

\section{RESULTS AND DISCUSSION}

\subsection{Classical Assumption Test}

a. Test for normality with Kolmogorov-Smirnov

Table 1

One-Sample Kolmogorov-Smirnov Test

\begin{tabular}{llr}
\hline & & $\begin{array}{c}\text { Standardized } \\
\text { Residual }\end{array}$ \\
\hline $\mathrm{N}$ & & 60 \\
\hline Normal Parametersa,b & Mean & 0,0000000 \\
& Std. & 0,94778958 \\
& Deviation & 0,113 \\
Most Extreme & Absolute & 0,064 \\
Differences & Positive & $-0,113$ \\
\hline Test Statistic & Negative & 0,113 \\
\hline Asymp. Sig. (2-tailed) & & $0,053^{c}$ \\
\hline
\end{tabular}

The results of normality testing using Kolmogorov Smirnov showed that the significance value of 0.053 was greater than 0.05 . This shows that the regression equation for the model in this study has a normal distribution of data. 
b. Multicollinearity Test

In multicollinearity testing there is no multicollinearity, because the VIF values of all $b=$ variables are less than 10, while the Tolerance Value is above 0.10 .

Table 2

Multicollinearity Test

\begin{tabular}{lllr}
\hline \multirow{2}{*}{ Model } & \multicolumn{2}{c}{ Collinearity Statistics } \\
\hline 1 & Tolerance & VIF \\
\cline { 2 - 4 } & (Constant) & & \\
\cline { 2 - 4 } & X1_UKURAN_PERUSAHAAN & 0,691 & 1,448 \\
\cline { 2 - 4 } & X2_ROA & 0,539 & 1,854 \\
\cline { 2 - 4 } & X3_KEBIJAKAN_DIVIDEN & 0,711 & 1,407 \\
\cline { 2 - 4 } & X4_STRUKTUR_AKTIVA & 0,503 & 1,986 \\
\cline { 2 - 4 } & X5_PERTUMBUHAN_PENJUA & 0,861 & 1,162 \\
& LAN & 0,863 & 1,159 \\
\cline { 2 - 4 } & X6_FREE_CASH_FLOW & & \\
\end{tabular}

c. Heterokedasticity Test with Glejser

It can be seen that the variable company size, profitability, dividend policy, asset structure, sales growth and free cash flow show a significant value greater than 0.05 , so it can be concluded free from heteroscedasticity problems.

d. Autocorrelation Test

Table 3

Autocorrelation Test

\begin{tabular}{llrrrr}
\hline Model & $\mathrm{R}$ & R Square & $\begin{array}{c}\text { Adjusted R } \\
\text { Square }\end{array}$ & $\begin{array}{l}\text { Std. Error of } \\
\text { the Estimate }\end{array}$ & $\begin{array}{l}\text { Durbin- } \\
\text { Watson }\end{array}$ \\
\hline 1 & $0,813^{\mathrm{a}}$ & 0,661 & 0,623 & 0,17679 & 1,013 \\
\hline
\end{tabular}

Durbin-Watson value of 1.013 means that the value of the data is between -2 to 2 , and can be concluded free from autocorrelation. 
e. Multiple Linear Regression Analysis

Table 4

Regression Analysis

\begin{tabular}{|c|c|c|c|c|c|}
\hline \multirow[b]{2}{*}{ Model } & \multicolumn{5}{|c|}{$\begin{array}{c}\text { Standardize } \\
\mathrm{d} \\
\text { Coefficients }\end{array}$} \\
\hline & $\mathrm{B}$ & Error & Beta & $\mathrm{T}$ & Sig. \\
\hline 1 (Constant) & $-0,542$ & 0,409 & & $-1,326$ & 0,191 \\
\hline X1_UKURAN_PERUSAHAAN & 0,064 & 0,014 & 0,432 & 4,487 & 0,000 \\
\hline X2_ROA & $-4,862$ & 0,620 & $-0,854$ & $-7,845$ & 0,000 \\
\hline X3_KEBIJAKAN_DIVIDEN & $-0,144$ & 0,050 & $-0,274$ & $-2,885$ & 0,006 \\
\hline X4_STRUKTUR_AKTIVA & $-0,605$ & 0,216 & $-0,315$ & $-2,798$ & 0,007 \\
\hline X5_PERTUMBUHAN_PENJUALAN & 0,116 & 0,153 & 0,065 & 0,754 & 0,454 \\
\hline X6_FREE_CASH_FLOW & 0,003 & 0,005 & 0,052 & 0,601 & 0,550 \\
\hline
\end{tabular}

Based on the table above we get the following double linear regression equation:

$Y=-0,542+0,064 X 1-4,862 X 2-0,144$ X3 -0,605 X4 + 0,116 X5 + 0,003 X6 + e

Explanation :

$\mathrm{Y}=$ Debt Policy $(\mathrm{DER})$

$\mathrm{a}=$ constant

$\mathrm{X} 1$ = Company Size

$\mathrm{X} 2=$ Profitability $(\mathrm{ROA})$

X3 = Dividend Policy

$\mathrm{X} 4=$ Asset Structure

X5 = Sales Growth

X6 = Free Cash Flow 
f. goodness of fit

1). Coefficient of Determination

Table 5

Coefficient of Determination

\begin{tabular}{|c|c|c|c|c|}
\hline Model & $\mathrm{R}$ & R Square & $\begin{array}{l}\text { Adjusted R } \\
\text { Square }\end{array}$ & $\begin{array}{l}\text { Std. Error of the } \\
\text { Estimate }\end{array}$ \\
\hline 1 & $0,813^{a}$ & 0,661 & 0,623 & 0,17679 \\
\hline
\end{tabular}

The adjusted R Square (R2) value of 0.623 or $62.3 \%$ shows the influence exerted by the independent variables of company size $(\mathrm{X} 1)$, profitability $(\mathrm{X} 2)$, dividend policy $(\mathrm{X} 3)$, asset structure (X4), sales growth (X5) and free cash flow (X6) is 62.3\%, while the remaining $37.7 \%$ is influenced by other variables such as managerial ownership, institutional ownership, business risk and others.

2). F test

Table 6

F test

\begin{tabular}{lllrrrr}
\hline \multirow{2}{*}{ Model } & \multicolumn{2}{c}{$\begin{array}{c}\text { Sum of } \\
\text { Square }\end{array}$} & Df & Mean Square & F & Sig. \\
\hline \multirow{2}{*}{1} & Regression & 3,233 & 6 & 0,539 & 17,238 & $0,000^{\mathrm{b}}$ \\
\cline { 2 - 7 } & Residual & 1,657 & 53 & 0,031 & & \\
\cline { 2 - 7 } & Total & 4,889 & 59 & & & \\
\hline
\end{tabular}

From the regression model above shows that the $F$ value of 17.238 with a significant value of 0.000 less than 0.05 , the degree of freedom is obtained; $a,(k-1)$, (nk) or 0.05 (61) (60-6) obtained $F$ table at a 95\% confidence level of 2.39, thus Fcount $>$ Ftable (17.238> 2.39) . From the results of the $\mathrm{F}$ test this means that company size, profitability, dividend policy, asset structure, sales growth, free cash flow together have a positive and significant effect on debt policy. 
3). T test

\section{Table 7}

T test

\begin{tabular}{|c|c|c|c|c|c|}
\hline \multirow[b]{2}{*}{ Model } & \multicolumn{3}{|r|}{$\begin{array}{c}\text { Standardize } \\
\text { d } \\
\text { Coefficients } \\
\end{array}$} & \multirow[b]{2}{*}{$\mathrm{t}$} & \multirow[b]{2}{*}{ Sig. } \\
\hline & B & $\begin{array}{l}\text { Std. } \\
\text { Error }\end{array}$ & Beta & & \\
\hline 1 (Constant) & $-0,542$ & 0,409 & & $-1,326$ & 0,191 \\
\hline X1_UKURAN_PERUSAHAAN & 0,064 & 0,014 & 0,432 & 4,487 & 0,000 \\
\hline X2_ROA & $-4,862$ & 0,620 & $-0,854$ & $-7,845$ & 0,000 \\
\hline X3_KEBIJAKAN_DIVIDEN & $-0,144$ & 0,050 & $-0,274$ & $-2,885$ & 0,006 \\
\hline X4_STRUKTUR_AKTIVA & $-0,605$ & 0,216 & $-0,315$ & $-2,798$ & 0,007 \\
\hline $\begin{array}{l}\text { X5_PERTUMBUHAN_PENJUA } \\
\text { LAN }\end{array}$ & 0,116 & 0,153 & 0,065 & 0,754 & 0,454 \\
\hline X6_FREE_CASH_FLOW & 0,003 & 0,005 & 0,052 & 0,601 & 0,550 \\
\hline
\end{tabular}

\subsection{Discussion}

a. Effect of company size on debt policy

Based on the results of testing the influence of company size variables (X1) obtained a significance value of $0,000<0.05$ and ttable $=n-(k-1)$ so the value of ttable 60- (6-1) found ttable 2.005 then tcount>ttable $(4.487>2.005)$, then the size of the company $(X 1)$ has a positive and significant effect on debt policy, so it can be concluded that $\mathrm{H} 1$ is accepted, the higher the size of the company will increase the company's debt.

The results of this study are in line with research conducted by Nafisa (2016), Irawan (2016), Mardiyati (2018), Novitasari (2015), Ifada (2017) which states in their research that company size has a positive and significant effect on debt policy. The results showed that the larger the size of a company, the company will require greater costs to carry out operational activities such as labor costs, administrative and general costs and maintenance costs of buildings, machinery, vehicles and equipment that will affect the company's debt.

A positive value in the statistical test explains that large companies will definitely need more funds compared to smaller companies. This decision is related to pecking order theory which states that if there is insufficient retained earnings, the debt will be the next decision.

b. Effect of profitability on debt policy

Based on the results of testing the effect of the profitability variable (X2) obtained a significance value of $0,000<0.05$ and ttable $=n-(k-1)$ so the value of ttable $60-(6-1)$ found 
ttable 2.005 then tcount>ttable $(-7.845>2.005)$, then profitability (X2) has a negative and significant effect on debt policy, so it can be concluded $\mathrm{H} 2$ is accepted, the higher the profitability will reduce the level of corporate debt.

The results of this study are in line with research conducted by Novitasari (2015) and Irawan (2016), Ahyuni(2018) and Sheisarvian (2015) which states that profitability has a negative and significant effect on debt policy. The results showed that companies with declining prospects would prefer to sell shares and reduce debt more. Increased profitability will result in a decrease in the use of corporate debt.

c. Effect of dividend policy on debt policy

Based on the test results of the influence of the divient policy variable (X3) obtained a significance value of $0.006<0.05$ and ttable $=n-(k-1)$ so the value of $60-(6-1)$ found ttable 2.005 then tcount $>$ ttable $(-2.885>2,005)$, then the dividend policy $(\mathrm{X} 3)$ has a negative and significant effect on the debt policy, so it can be concluded that $\mathrm{H} 3$ is rejected, the higher the dividend policy will reduce the level of corporate debt.

This is in accordance with research conducted by Sheisarvian (2015) which states that dividend policy has a negative and significant effect on debt policy. This is due to the negative relationship that occurs in the company for the first time the company will take advantage of funding from retained earnings, if retained earnings are insufficient then it will be used funding with debt. This shows that the greater the dividend policy, the smaller the debt used by the company, and vice versa.

d. Effect of asset structure on debt policy

Based on the results of testing the influence of asset structure variables (X4) obtained a significance value of $0.007<0.05$ and ttable $=n-(k-1)$ so the value of $60-(6-1)$ found ttable 2.005 then tcount $>$ ttable $(-2.798>2,005)$, then the asset structure $(\mathrm{X} 4)$ has a negative and significant effect on debt policy, so it can be concluded that H4 is rejected, the higher the asset structure will reduce the level of corporate debt.

This is consistent with research conducted by Herdiana (2016) which states that asset structure has a negative and significant effect on debt policy. This is due to the high percentage of asset structure owned by the company so that the assets owned by the company are sufficient to be used to carry out the operational activities of a company and reduce the use of debt. 
e. Effect of sales growth on debt policy

Based on the results of testing the effect of sales growth variables (X5) obtained a significance value of $0.454>0.05$ and ttable $=n-(k-1)$ so the value of $60-(6-1)$ found ttable 2.005 then tcount>ttable $(0.754<2.005)$, then sales growth $(\mathrm{X} 5)$ does not have a positive and significant effect on debt policy, so it can be concluded that $\mathrm{H} 5$ is rejected, then the high and low level of sales growth does not affect the level of corporate debt policy.

This is in accordance with research by Novitasari (2015) which states that sales growth has no positive and insignificant effect on debt policy. This is because companies that have relatively stable sales have relatively stable cash flows and have high revenues, meaning they have the ability high internal funding.

f. Effect of free cash flow on debt policy

Based on the test results the influence of the variable free cash flow (X6) obtained a significance value of $0.550>0.05$ and ttable $=n-(k-1)$ so the value of $t 60$. (6-1) found ttable 2.005 then tcount $>$ ttable $(0.601<2,005)$, then free cash flow $(X 6)$ does not have a positive and significant effect on debt policy, so it can be concluded that H6 is rejected, so the level of free cash flow does not affect the level of corporate debt policy.

The results of this research are consistent with the results of research conducted by Natasia (2016) which states that free cash flow has no positive and insignificant effect. A positive relationship occurs if the free cash flow has increased, the company's debt policy will also add value to the company's funding activities and vice versa.

\section{CONCLUSION AND IMPLICATIONS}

\subsection{Conclusion}

Based on the results of research and discussion that has been described, then to answer the identification of problems that have been formulated researchers draw conclusions as follows:

a. Company size has a positive and significant effect on debt policy on manufacturing companies that have been listed on the Indonesia Stock Exchange in 2015-2018.

b. Profitability has a negative and significant effect on debt policy on manufacturing companies that have been listed on the Indonesia Stock Exchange in 2015-2018. 
c. Dividend Policy has a negative and significant effect on debt policy on manufacturing companies that have been listed on the Indonesia Stock Exchange in 2015-2018.

d. Asset Structure has a negative and significant effect on debt policy on manufacturing companies that have been listed on the Indonesia Stock Exchange in 2015-2018.

e. Sales growth does not have a positive and significant effect on debt policy on manufacturing companies that have been listed on the Indonesia Stock Exchange in 2015-2018.

f. Free Cash Flow has no positive and insignificant effect on debt policies for manufacturing companies that have been listed on the Indonesia Stock Exchange in 2015-2018.

\subsection{Implication}

Based on the results of this study, the following implication can be given:

a. For Companies

Companies are advised to pay more attention and be careful in determining the source of funding decisions that reflect the condition of the company, which includes company size, profitability, dividend policy, asset structure, sales growth and free cash flow so that the company can improve company performance in financial management and improve quality company.

b. For Investors and Prospective Investors

Investors and potential investors are advised to pay attention to company size, profitability, dividend policy, asset structure, sales growth and free cash flow in investment considerations so as to improve company performance.

c. For Academics

Limitations in this study are expected to be refined further in future studies, especially regarding the effect of company size, profitability, dividend policy, asset structure, sales growth and free cash flow by adding a number of samples that are not only focused on manufacturing companies. Moreover, it can add other variables that affect debt policy in addition to the variables used in this study. 
d. For further researchers

1) This study only uses research samples in manufacturing companies with a time span of four years. It is recommended in further research to increase the time span, so that research results become more representative in using a longer time span.

2) This study only uses variables of company size, profitability, dividend policy, asset structure, sales growth and free cash flow to determine the effect on debt policy. It is recommended to further researchers to examine the financial variables that have a greater influence on debt policy such as managerial ownership, institutional ownership, business risk and others.

\section{REFERENCES}

Ahyuni (2018), "The Effect of Free Cash Flow, ROA and Management Ownership on Debt Policy in an Empirical Study of Property and Real Estate Companies Listed on The Indonesia Stock Exchange 2014-2016" , conference progress, Vol. 1, August, 1 2018, P ISSN: 2622-3031.

Akoto (2014), "What Determines the Debt Policy of Listed Manufacturing Firms in Ghana ?" , International Business Research, Vol. 7, No. 1, ISSN 1913-9004, E-ISSN 1913-9012.

Andriati (2016), "The Influence of Managerial Ownership, Institutional Ownership, Dividends, Company Growth, Free Cash Flow and Profitability on The Company's Debt Policy. Journal of Regional Accounting \& Finance, Vol. 11, No. 2, November 2016, pp. 16-32.

Escolano (August 2016), Optimal Debt Policy Under Asymmetric Risk. International Monetary Fund.

Fahmi (2014), Corporate Financial Management and Capital Markets, Jakarta: Media Discourse Partner.

Fahmi (2018), Introduction to Financial Management, Bandung: Alfabeta.

Ghozali, I. (2016), "Multivariate Analysis Application with IBM SPSS 23 Program", Semarang: Diponegoro University Publisher Agency.

Gumanti (2013), "Dividend Policy Theory, Empirical and Implications" , Yogyakarta: UPP STIM YKPN.

Halim, Abdul (2015), Business Financial Management, Concepts and Applications, Jakarta: Mitra Wacana Media. 
Hanafi, M. (2016), "Financial Management" , Yogyakarta: PBFE Yogyakarta.

Hendria (2015), "The Influence of Insider Ownership, Firm Size, Firm Growth, and Business Risk on Debt Policy in Publicly Listed Banking Companies Listed on The IDX" , FEKON jom, Vol. 2, No. 1, February 2015.

Houston, B. D. (2010), "Fundamentals of Financial Management" , Jakarta: Four Salemba.

Husna (2016), "The Effect of Company Size, Profitability and Business Risk on Debt Policy", The Journal Said Economics, Vol. 10, No. 2, December 2016, ISSN: 1978-5275.

Ifada (2017), "Factors Affecting Debt Policy Empirical Study of Manufacturing Companies Listed on The Indonesia Stock Exchange in 2012-2014" , Accounting and Auditing Journal, Vol. 14, No. 1, pp. 40-54, 2017, ISSN: 2549-7650.

Indraswary (2016), "Factors Affecting Debt Policy in Property and Real Estate Companies Listed on The Indonesia Stock Exchange 2010-2014", Journal of Accounting, Vol. 2, No. 2, March 2016.

Putu, I. (2017), "The Effect of Free Cash Flow, Asset Structure, Business Risk and Profitability on Debt Policy" , Eud Management E-Journal, Vol. 6, No. 1, 2017, pp. 60-86 ISSN: 23028912.

Irawan (2016), "The Influence of Tangible Assets, Company Size, Company Growth, Company Duration, and Profitability on Debt Policy on Manufacturing Companies Listed on The Indonesia Stock Exchange in 2010-2014" , Journal Accounting, Vol. 2, No. 2, March 2016.

Cashmere (2018), "Analysis of Factors Affecting Debt Policy Case Studies on Companies that Go Public on the IDX", Executive Journal, Analysis of Financial Statements. Depok: Rajawali, Press.Sustainable. Vol 15, No. 1, June 2018, ISSN: 1829-7501.

Malte, R. (2017), "Capital Taxtion and Goverment Dept Policy with Public Discounting" , German Institute for Economic Research, No. 1697, ISSN: 1619-4535, july 152017.

Mardiyati (2018), "The Effect of Managerial Ownership, Asset Structure, Company Size, Sales Growth, and Profitability on Policies in Various Industry Sector Companies Listed on The Indonesia Stock Exchange 2012-2016 period" , Management Research Journal, Vol. 9 No. 1, 2018, E-ISSN: 2301-8313.

Nafisa (2016), "The Influence of Managerial Ownership, Institutional Ownership, Company Size, Company Growth, Free Cash Flow and Profitability on The Debt Policy of 
Manufacturing Companies Listed on the IDX 21 year", Economics and Business Journal, No. 2, October .

Natasia, W. (2015), "Factors that Influence the Company's Debt Policy Listed on the IDX" , iilmu journal \& accounting research, Vol. 4, No. 1, pp. 1-22.

Sari, Novita (2015), "Analysis of Factors Affecting Debt Policy in a Study of Manufacturing Companies Listed on the IDX in 20019-2013", Diponegoro Journal of Management, Vol. 4, No. 2, pp. 1-12, ISSN: 2337-3792.

Putra (2017), "The Influence of Free Cash Flow, Company Growth, Profitability, Company Size, Managerial Ownership and Asset Structure on Debt Policies in Manufacturing Companies Listed on the Stock Exchange in 2013-2016".

Rahmadani. (2018), "Debt Policy on Major Sector Companies Listed on the Indonesia Stock Exchange in 2013-2016" , JWEM STIE MICROSCI, ISSN 2622-6421, Vol. 8, No. 02, October.

Sheisarvian (2015), "The Influence of Managerial Ownership, Dividend Policy, Profitability on Debt Policy in Manufacturing Companies that were Listed on the Stock Exchange in the period of 2010-2012", Business Administration Journal (JAB), Vol. 22, May 1.

Sulhan (2018), "The Impact of Ownership Structure and Profitability on Debt Policy with Dividend Policy as A Moderating Variable", A Study of the Property Sector, Real Estate and Building Construction Registered at BEI. national seminar and call for paper: management, accounting and banking.

Sugiyono (2015), Combination research methods (mix methods). Bandung: Alfabeta.

Syriac, "Analysis of Factors Affecting Debt Policy", Accounting Analysis Journal, Vol. 5 , No. 2, may 2016, issn: 2252-6765, pp. 95-103.

Syriac, (2013), "The Effect of Free Cash Flow, Company Growth, Dividend Policy and Company Size on Company Debt Policy in A Study of Manufacturing Companies Listed on the IDX in 2013" , Dynamics of Accounting, Management, Banking, Vol. 4 No. 1 ISSN: 19794878, pp. 20-28.

Waluyo. (2018), "Do Efficiency Of Taxes, Profitability,and size of companes affect debt? A study of compaines listed in the Indonesia Stock Exchange", Europan Research Studies Journal , Vol. XXL Issue: 1, pp. 331-339. 